\title{
A Study of the Cytochrome $c$ Haemochromogen
}

\author{
By E. MARGOLIASH, NEHAMAH FROHWIRT AND EDITH WIENER \\ Department of Experimental Pathology, The Hebrew University-Hadassah Medical School, \\ Jerusalem, Israel, and the Molteno Institute, University of Cambridge
}

(Received 12 May 1958)

A study of the relationship of the structure of the horse-heart cytochrome $c$ haemochromogen to the enzymic activity of the protein could be undertaken in view of: $(a)$ the firm thio ether bonds which link the protein to the haem (Theorell, 1938; Theorell, 1939; Paul, 1951), enabling the isolation, after proteolytic digestion, of a relatively small portion of the protein adjacent to the haem (Tsou, $1951 a, b)$, and $(b)$ the isolation, by column chromatography on cation exchangers, of a graded series of denatured forms of the protein, showing a gradation of concomitant changes in enzymic activity, on the one hand, and of various typical properties of the cytochrome $c$ haemochromogen, such as the $\mathrm{pH}$ range of stability of the reduced spectrum and the percentage combination with carbon monoxide, etc., on the other.

While this work was in progress a series of papers by Tuppy \& Bodo $(1954 a-c)$ and Tuppy \& Paleus (1955) established the following amino acid sequence for that part of the cytochrome $c$ protein next to the haem:

$$
\begin{aligned}
& \text { Val. Glu }\left(\mathrm{NH}_{2}\right) \text {. Lys. Cys. Ala. Glu }\left(\mathrm{NH}_{2}\right) \text {. } \\
& \begin{array}{llllll}
1 & 2 & 3 & 4 & 5 & 6
\end{array} \\
& \text { Cys.His.Thr. Val. Glu.Lys } \\
& \begin{array}{llllll}
7 & 8 & 9 & 10 & 11 & 12
\end{array}
\end{aligned}
$$

The haem was bound to the chain through thio ether bonds to the two cysteine residues. The amino acids 4-12 occurred in the product isolated after trypsin digestion of horse-, ox- and pig-heart cytochrome $c$, and the amino acid sequence 1-11 was found in the corresponding pepsin-digestion product from ox and salmon cytochrome $c$, and serine replaced the alanine in position 5 in chicken cytochrome c. In a more recent report Tuppy (1957) found that the sequence 1-11 occurred also in horse-heart cytochrome $c$, and in silkworm cytochrome $c$ arginine replaced the lysine in position 3.

Paleus, Ehrenberg \& Tuppy (1955) have made a spectrophotometric, titrimetric and magnetometric study of the pepsin-digested product (pepsindigested cytochrome c (core'); Ehrenberg \& Theorell (1955), on the basis of spectrophotometric studies and molecular weights of this product estimated by ultracentrifugal sedimentation, have proposed a detailed structural model of the 'core' as well as of the whole cytochrome $c$ molecule.
The present paper confirms for horse-heart cytochrome $c$ the sequence established by Tuppy \& Paleus (1955) for the pepsin-digested 'core' from various cytochromes $c$, and presents the results of a study of some of the properties of a series of denatured horse-heart cytochromes $c$, the pepsin digested 'core' being considered as the most degraded form of the haemochromogen. Evidence for a proposed structural model of this peptide is given in a study of its sedimentation characteristics, and numerical data on the spectrum of purified horse-heart cytochrome $c$ are included in the Appendix to this paper.

A similar confirmation of the amino acid sequence of pepsin-digested horse-heart cytochrome c 'core' has been announced by Leaf \& Gillies (1955) and a preliminary report of part of the present work has been presented (Margoliash, 1955).

\section{MATERIALS AND METHODS}

Cytochrome c. This was prepared from horse hearts by the method of Keilin \& Hartree (1945) and purified by chromatography on Amberlite IRC-50 columns (Margoliash, $1954 b$ ). Fraction I (enzymically active) was eluted with 0.25 M-ammonium acetate, and the enzymically less-active fraction II was divided into three parts by successive elutions with $0.5 \mathrm{M}$-ammonium acetate (II a), $0.75 \mathrm{M}$ ammonium acetate (II $b$ ) and $\mathrm{M}$-ammonium acetate (IIc).

The activities of the various cytochrome $c$ fractions in the cytochrome oxidase and succinic oxidase systems, their iron contents and rate of ascorbic acid oxidation as well as the dry weights of the heart-muscle preparations were determined as described by Margoliash (1954a). Total sulphur was determined by digestion in sealed capillary tubes with fuming $\mathrm{HNO}_{3}$ containing $90 \%$ (w/v) of $\mathrm{HNO}_{3}$ at $300-350^{\circ}$ for $6 \mathrm{hr}$., and precipitating the sulphate formed as benzidine sulphate, in acetone, and determining the precipitated benzidine colorimetrically (Letonoff \& Reinhold, 1936).

Preparation of the pepsin-digested cytochrome c 'core'. Cytochrome $c$ fraction I $(1 \mathrm{~g}$. $)$ in $100 \mathrm{ml}$. of $0.5 \mathrm{M}$-acetic acid was digested with $50 \mathrm{mg}$. of twice-recrystallized pepsin (Worthington Biochemical Co., St Louis, Mo., U.S.A.) at $37^{\circ}$ for $48 \mathrm{hr}$. The pepsin coagulated on boiling for $4 \mathrm{~min}$., was filtered off and the 'core' precipitated by dialysing against several changes of distilled water. The precipitated peptide containing the cytochrome $c$ haem was separated by centrifuging, redissolved in a minimal volume of aq. $0.05 \mathrm{~N}-\mathrm{NH}_{3}$ soln. and reprecipitated by dialysis against water, adding two drops of acetic acid/l. to the outer fluid 
of the third change of water. This procedure was repeated once more. The final precipitate was dissolved in aq. $0.01 \mathrm{~N}-\mathrm{NH}_{3}$ soln. and percolated through a column $\left(1 \mathrm{~cm} . \times 10 \mathrm{~cm}\right.$.) of Amberlite IRC-50 in the $\mathrm{NH}_{4}^{+}$form to remove any traces of partially digested material. The filtrate was dialysed against several changes of aq. mN$\mathrm{NH}_{3}$ soln. and freeze-dried over $\mathrm{H}_{2} \mathrm{SO}_{4}$. Yield: 90-110 mg.; iron content: $2 \cdot 09-2 \cdot 66 \%$, corresponding to $16-12$ amino acid residues. This preparation is similar to the 'pepsin modified cytochrome $c$ ' obtained by Tsou (1951 $a$ ). The highest yields were obtained by keeping the volumes of the solution dialysed to a minimum. The 'core' precipitated at slightly acid $\mathrm{pH}(4 \cdot 5-5 \cdot 5)$, but tended to diffuse through the cellophan tubing readily at lower $\mathrm{pH}$ values, and at slightly alkaline $\mathrm{pH}(8-8.5)$ it did not precipitate and did not diffuse appreciably out of the dialysis tubing.

The haem could be separated from the peptide attached to it by the method of Paul (1950). Silver acetate was used and the heating at $55^{\circ}$ had to be continued for 10-12 hr. in order to remove the haem entirely, as compared with the $90 \mathrm{~min}$. used by Paul for cytochrome $c$. The excess of silver was removed by adsorption on a column of Amberlite IRC-50, which did not retain either the haem or the peptide. The cysteines were oxidized to cysteic acid with performic acid (Sanger, 1949a). This performic acid treatment of the haem-containing peptide split the haem off quantitatively, so that the preliminary removal of the haem by the silver-salt technique of Paul (1950) was unnecessary and was omitted in later experiments.

Studies of amino acid sequence. The methods used were essentially those developed by Sanger et al. (Sanger, 1949b; Sanger \& Tuppy, 1951 $a$; Sanger \& Thompson, 1953a). Total hydrolysis of peptides was carried out in sealed capillary tubes in glass-distilled 5.6 N-HCl at $105^{\circ}$ for $18 \mathrm{hr}$. Semi-quantitative estimations of the amino acids after two-dimensional paper chromatography were performed by the ninhydrin method of Fowden (1951). Histidine was determined separately according to Macpherson (1942) after elution with $0 \cdot 1 \mathrm{~N}-\mathrm{HCl}$ from one-dimensional paper chromatograms developed with the butan-1-ol-formic acidwater (75:15:10, by vol.) mixture of Acher \& Crocker (1952). Dinitrophenyl amino acids (DNP-amino acids) were estimated spectrophotometrically after elution from paper chromatograms with $35 \%(\mathrm{v} / \mathrm{v})$ acetic acid in water. The solvents used for development of the chromatograms were butanol-formic acid-water (Acher \& Crocker, 1952) for the DNP-derivatives of histidine and $\epsilon$-DNP-lysine, and tert.-amyl alcohol-phthalate buffer (Blackburn \& Lowther, 1951) for the other DNP-amino acids.

Paper electrophoresis was carried out with strips of Whatman no. $3 \mathrm{MM}$ paper $20 \mathrm{~cm}$. wide, stretched on a glass frame immersed in a tank containing carbon tetrachloride. The buffer used for the electrophoresis of the 'core', the haem-free peptide and the oxidized peptide mixture was $0.05 \mathrm{M}$-ammonium acetate, $\mathrm{pH} 7.0$, and that used for the peptide mixture resulting from partial hydrolysis was a collidine-acetic acid buffer, $\mathrm{pH} 7 \cdot 0$, according to Lockhart \& Abraham (1954).

Partial hydrolysates were obtained directly from the whole pepsin-digested cytochrome $c$ 'core' by incubating at $37^{\circ}$ with $12 \mathrm{~N}-\mathrm{HCl}$, for 8 and for 12 days, $50 \mathrm{mg}$. of 'core' being used for each experiment. The peptide mixture was separated into a neutral fraction and several acid and basic fractions by paper electrophoresis; $5-8 \mathrm{mg}$. of the mixture was applied on each $10 \mathrm{~cm}$. of the starting line of the electrophoresis paper. With the 8 days' hydrolysate the peptides were separated into groups by paper electrophoresis and each group was separately oxidized by performic acid, whereas with the 12 days' hydrolysate the whole mixture was oxidized before electrophoresis. A side strip of each paper was developed with $0.2 \%$ ninhydrin in propan-2-ol, the fractions were eluted separately with water, the peptides resolved on two-dimensional paper chromatograms and localized by spraying with $0.02 \%$ ninhydrin.

The amino acids of each peptide were identified by paper chromatography after total hydrolysis, and the $N$-terminal residue was identified after reaction with 1-fluoro-2:4dinitrobenzene (FDNB) in $1 \%$ trimethylamine. The ninhydrin-reacting amino acids remaining after dinitrophenylation and the DNP-amino acids produced were identified after total hydrolysis on suitable paper chromatograms. Two-dimensional chromatograms for free amino acids were developed first with phenol saturated with water, the cabinet containing in separate jars 11 . of water to which $10 \mathrm{ml}$. of aq. $\mathrm{NH}_{3}$ soln. (sp.gr. 0.880) was added, and $250 \mathrm{ml}$. of water-saturated phenol to which $20 \mathrm{~g}$. of $\mathrm{KCN}$ was added. For peptides the amount of aq. $\mathrm{NH}_{3}$ soln. (sp.gr. 0.880) added to the water was decreased to $30 \mathrm{ml}$., the volume used by Sanger \& Tuppy $(1951 a)$. In the second dimension the solvent used was butan-1-ol-acetic acidwater (50:10:40, by vol.), aged for 10 days. The abbreviations for the amino acids and the methods for referring to peptides are those used by Sanger \& Tuppy (1951 $a$ ), and the method for indicating the relative strength of the ninhydrin amino acid coloration after paper chromatography is that of Consden, Gordon \& Martin (1949).

$\mathrm{pH}$-extinction curves. The effect of $\mathrm{pH}$ on the spectral absorption of the reduced forms of the various cytochrome $c$ fractions and the pepsin-digested 'core' was estimated by mixing equal volumes of a solution of known concentration of the protein and appropriate buffers, reducing the haemochromogen by adding a minimal amount of sodium dithionite to the solution in the spectrophotometer cell and reading the extinction immediately. The percentage combination with $\mathrm{CO}$ at various $\mathrm{pH}$ values was determined as described by Tsou (1951 $a$ ). The buffers used were: $0 \cdot 1 \mathrm{~N}$ $\mathrm{HCl}$ for $\mathrm{pH} 1$, sodium citrate- $\mathrm{HCl}$ for $\mathrm{pH} \mathrm{2-3,} \mathrm{sodium}$

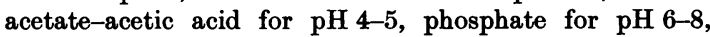
sodium borate- $\mathrm{NaOH}$ for $\mathrm{pH} \mathrm{9-12,} \mathrm{and} 0 \cdot 1 \mathrm{~N}-\mathrm{NaOH}$ for $\mathrm{pH}$ 13. The final buffer concentration was always $0.1 \mathrm{M}$ in the $\mathrm{pH}$ range 2-12, and the final $\mathrm{pH}$ of the mixtures was determined with a glass electrode. The $\mathrm{pH}$ scale was standardized with standard buffers. The actual position of the maxima around 550 and $520 \mathrm{~m} \mu$ and the minimum at $535 \mathrm{~m} \mu$ was found in each case. The spectrophotometers used were a Hilger Uvispek and a Beckman DU.

Ultracentrifuge studies. Most of the sedimentations were performed in a Svedberg oil-turbine ultracentrifuge at $900 \mathrm{rev} . / \mathrm{sec}$. and $26-28^{\circ}$. The diagonal-schlieren optical system was used (Philpot, 1938). The light source was a tungsten lamp. A wave band at approximately $600 \mathrm{~m} \mu$ was selected by means of a non-deviating prism: this wave band was found to give the least contrast between sedimenting 'core' and supernatant buffer on the photographic record. Optical-path lengths were 12 and $3 \mathrm{~mm}$. for reduced and oxidized 'core' respectively. Eight to 10 photographs were taken at $10 \mathrm{~min}$. intervals with $4 \mathrm{~min}$. 
exposures. A diagonal fibre replaced the knife edge in the optical system; the position of the concentration-gradient 'peak' was measured both at the upper and at the lower edge of the fibre image to correct for any effect of the photographic density gradient across the boundary on the apparent position of the 'peak'. Sedimentation coefficients were calculated by the method of Cecil \& Ogston (1948); for the reduced 'core' a standard error of $\pm 2 \%$ can be assumed.

An amount (5.1-5.7 mg.) of the pepsin-digested cytochrome $c$ 'core' was dissolved in $1.0 \mathrm{ml}$. of the requisite buffer solution and reduced by the addition of minimal amounts of solid sodium dithionite, under nitrogen. Determinations of $\mathrm{pH}$ of the final solution were made with a glass electrode.

For those sedimentations at $\mathrm{pH} 2 \cdot 0,3.0$ and 11.5 , done with a synthetic boundary cell (optical-path length $9 \mathrm{~mm}$.), a modified Spinco (Spinco Velocity Ultracentrifuge model E) motor-driven centrifuge was used at $877 \mathrm{rev} . / \mathrm{sec}$. and 23-26 ${ }^{\circ}$. The light source was a mercury-arc lamp, the whole mixed (unmonochromated) light output was used and the 'core' solution $(2.5 \mathrm{mg} . / \mathrm{ml}$. of buffer) was equilibrated with the buffer solution by a short dialysis. Photographs were taken at $5 \mathrm{~min}$. intervals with $1 \mathrm{~min}$. exposures. The rest of the procedure was the same as described above.

\section{RESULTS}

\section{Amino acid sequence of the pepsin-digested cytochrome c 'core'}

The pepsin-digested cytochrome $c$ 'core' appeared to be electrophoretically homogeneous at $\mathrm{pH} 7 \cdot 0$. However, after oxidation with performic acid, either directly or after preliminary removal of the haem by the silver-salt treatment, paper electro- phoresis showed three main peptides (marked $a, b$ and $c$ in Fig. 1) with peptide $c$ predominant and six other peptides in very much smaller yields, as judged by the ninhydrin coloration. Of the three main peptides, peptide $c$ contained all the amino acids present in the 'core', peptide $a$ lacked histidine and threonine and peptide $b$ lacked alanine (Table 1). In view of the overall sequence established by Tuppy \& Paleus (1955) and confirmed below, peptide $b$ represented the $C$-terminal half of the peptide beginning at the glutamic acid residue between the two cysteines, and peptide $a$ the $N$-terminal half ending at the alanine residue between the two cysteines. This was also confirmed by the trace of DNP-glutamic acid formed in the reaction of the 'core' with FDNB (Table 1). Every one of the nine peptides separated by paper electrophoresis was shown to contain cysteic acid. Since the attachment of the peptide chain of the 'core' to the haem is through thio-ether bonds, including the $S$ atoms of both cysteine residues which were oxidized to cysteic acid by the performic acid treatment, every one of these peptides was originally attached to the haem, and formed part of the same overall amino acid sequence. It was thus unnecessary to determine the amino acid sequence of each peptide separately, and the entire 'core' preparation was used for the preparation of partial hydrolysates.

Fig. 1 shows a typical electrophoresis pattern of such a partial acid hydrolysate, and Table 2 lists the sequence of the peptides which were isolated from two-dimensional paper chromatograms of

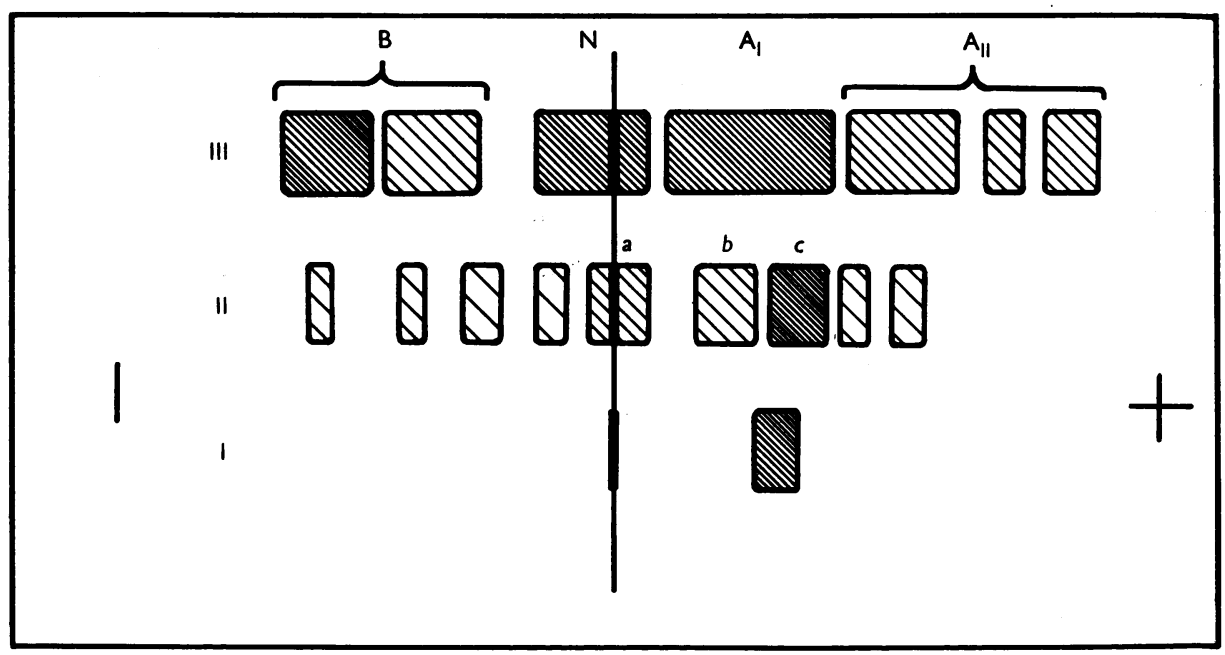

Fig. 1. Paper-electrophoresis pattern of pepsin-digested horse-heart cytochrome $c$ 'core' (I), pepsin-digested cytochrome $c$ 'core' after oxidation with performic acid (II), and 12 days' acid hydrolysate of pepsin-digested cytochrome $c$ 'core' (III). $A_{I}, A_{I I}, N$ and $B$ indicate the acidic fractions I and II, the neutral and the basic fractions respectively, of the 12 days' acid hydrolysate; $a, b$ and $c$ indicate the three main peptides present in the performic acid-oxidized 'core' (see Table 1). Buffer: 0.05 M-ammonium acetate, $\mathrm{pH} 7.0 ; 12 \mathrm{v} / \mathrm{cm}$.; $2.5 \mathrm{hr}$. 
various electrophoretic fractions of the 8 and 12 days' partial hydrolysates. The results given in Table 2, representing those peptides which could be isolated and identified with certainty, are sufficient to establish the required sequence of amino acids. All of the peptides identified, except
Ala.Cys, could be fitted into the following unique sequence (see Table 3):

Val.Glu.Lys.Cys.Ala.Glu.Cys.His.Thr.

Val.Glu.Lys.

The peptide, Ala.Cys, which does not form part of

\section{Table 1. Amino acid composition of pepsin-digested horse-heart cytochrome c 'core' and of peptides obtained from it after oxidation with performic acid}

Amino acids were estimated according to Fowden (1951) after paper chromatography. Cysteine was estimated from determination of total S. Histidine was determined by the Pauly reaction according to Macpherson (1942). The relative intensities of amino acids after ninhydrin reaction are indicated by + signs; - indicates none found. Yields of DNP-amino acids are not corrected for destruction during acid hydrolysis. Substitution at the e-nitrogen atom of lysine is indicated by $\epsilon$ and at the imidazole nitrogen atom of histidine by im.

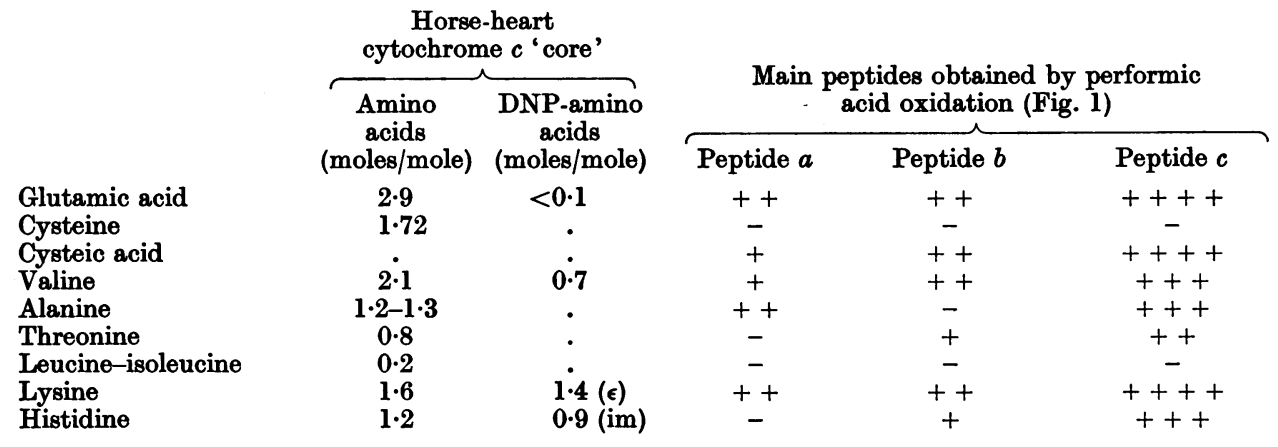

Table 2. Peptides obtained from acid hydrolysates of pepsin-digested horse-heart cytochrome c 'core'

The order of the residues given in parentheses was not determined. Free amino acids found in the electrophoretic fractions were not included in the Table, and peptides found in more than one electrophoretic fraction were mentioned only under the fraction in which they occurred most abundantly. Chromatographic solvents are given under Methods. Peptides 1-5 were found in the neutral fraction of the 8 days' hydrolysate. Peptides 6-12 were found in the acidic fraction I, peptides 13-15 in the acidic fraction II and peptides 16-19 in the neutral fraction of the 12 days' hydrolysate. Substitution at the $\epsilon$-nitrogen atom of lysine is indicated by $\epsilon$ and at the imidazole nitrogen atom of histidine by im.

\begin{tabular}{|c|c|c|c|c|c|c|}
\hline \multirow[b]{2}{*}{ No. } & \multicolumn{2}{|c|}{ Amino acids present } & \multirow{2}{*}{$\begin{array}{l}\text { DNP-amino } \\
\text { acids } \\
\text { identified }\end{array}$} & \multirow[b]{2}{*}{ Probable structure } & \multirow[b]{2}{*}{ Phenol } & \multirow{2}{*}{$\begin{array}{c}\text { Butanol- } \\
\text { acetic } \\
\text { acid- } \\
\text { water }\end{array}$} \\
\hline & In original peptide & $\begin{array}{c}\text { After DNP } \\
\text { treatment }\end{array}$ & & & & \\
\hline 1 & Glu, $\mathrm{Ala}, \mathrm{CySO}_{3} \mathrm{H}$ & Glu, $\mathrm{CySO}_{3} \mathrm{H}$ & & Ala. (Glu $\left.\mathrm{CySO}_{3} \mathrm{H}\right)$ & 0.02 & $0 \cdot 11$ \\
\hline 2 & Glu, Ala, CySO ${ }_{3} \mathrm{H}$, Lys & Glu, Ala, $\mathrm{CySO}_{3} \mathrm{H}$ & bis-Lys & Lys (CySO ${ }_{3} \mathrm{H}$. Ala.Glu) & $0 \cdot 27$ & $0 \cdot 08$ \\
\hline$\overline{3}$ & $\mathrm{Glu}, \mathrm{CySO}_{3} \mathrm{H}, \mathrm{His}$ & $\mathrm{CySO}_{3} \mathrm{H}$ & Glu, im-His & Glu (CySO $\mathrm{H}$. His) & $0 \cdot 30$ & $0 \cdot 27$ \\
\hline 4 & Glu, Lys, Val & Glu & $\epsilon$-Lys, Val & Val.(Glu.Lys) & 0.88 & 0.49 \\
\hline 5 & Val, Thr & Val & Thr & Thr.Val & 0.32 & $0 \cdot 87$ \\
\hline 6 & Glu, $\mathrm{CySO}_{8} \mathrm{H}$ & $\mathrm{CySO}_{3} \mathrm{H}$ & Glu & $\mathrm{Glu} \mathrm{CySO}_{3} \mathrm{H}$ & $0 \cdot 13$ & 0.08 \\
\hline 7 & Glu, Ala, CySO ${ }_{3} \mathrm{H}$, Lys, Val & Glu, Ala, $\mathrm{CySO}_{3} \mathrm{H}$ & $\epsilon-$ Lys, Val & Val. (Glu. Lys. CySO ${ }_{3} \mathrm{H}$. Ala) & $0 \cdot 24$ & 0.25 \\
\hline 8 & Glu, Ala & G]u & Ala & Ala Glu & $0 \cdot 30$ & $0 \cdot 45$ \\
\hline 9 & Glu, $\mathrm{CySO}_{3} \mathrm{H}, \mathrm{Lys}$, Val & Glu, $\mathrm{CySO}_{3} \mathrm{H}$ & $\epsilon$-Lys, Val & Val.(Glu.Lys. CySO $\left.{ }_{3} \mathrm{H}\right)$ & 0.55 & $0 \cdot 16$ \\
\hline 10 & Glu, Lys & & Glu, $\epsilon$-Lys & Glu.Lys & 0.68 & 0.31 \\
\hline 11 & Glu, Val, Thr & Glu, Val & Thr & Thr.(Val.Glu) & 0.65 & $0 \cdot 70$ \\
\hline 12 & Glu, Val & Glu' & $\mathrm{Val}$ & Val Glu & 0.60 & 0.76 \\
\hline 13 & $\mathrm{Ala}, \mathrm{CySO}_{3} \mathrm{H}$ & $\mathrm{CySO}_{3} \mathrm{H}$ & Ala & Ala. $\mathrm{CySO}_{3} \mathrm{H}$ & $0 \cdot 16$ & $0 \cdot 16$ \\
\hline 14 & $\mathrm{Ala}, \mathrm{CySO}_{3} \mathrm{H}$ & Ala & $\mathrm{CySO}_{3} \mathrm{H}$ & $\mathrm{CySO}_{3} \mathrm{H} \mathrm{Ala}$ & $0 \cdot 10$ & 0.40 \\
\hline 15 & Glu, Ala, CySO ${ }_{3} \mathrm{H}$ & Glu, Ala & $\mathrm{CySO}_{3} \mathrm{H}$ & $\mathrm{CySO}_{3} \mathrm{H}$. (Ala.Glu) & 0.24 & 0.51 \\
\hline 16 & $\mathrm{CySO}_{3} \mathrm{H}, \mathrm{Lys}$ & $\mathrm{CySO}_{3} \mathrm{H}$ & bis-Lys & $\mathrm{Lys} \mathrm{CySO}_{3} \mathrm{H}$ & $0 \cdot 16$ & 0.04 \\
\hline 17 & Glu, $\mathrm{CySO}_{3} \mathrm{H}, \mathrm{His}$ & $\mathrm{CySO}_{3} \mathrm{H}$ & Glu, im-His & Glu (CySO ${ }_{3} \mathrm{H}$. His) & $0 \cdot 27$ & $0 \cdot 06$ \\
\hline 18 & Glu, $\mathrm{CySO}_{8} \mathrm{H}, \mathrm{Lys}$ & $\mathrm{CySO}_{3} \mathrm{H}$ & Glu, $\epsilon$-Lys & Glu.(Lys. CySO $\left.{ }_{3} \mathrm{H}\right)$ & 0.33 & $0 \cdot 23$ \\
\hline 19 & Ala, $\mathrm{CySO}_{3} \mathrm{H}$, Lys & $\mathrm{Ala} \mathrm{CySO}_{3} \mathrm{H}$ & bis-Lys & Lys.(CySO H. Ala) & 0.52 & 0.14 \\
\hline
\end{tabular}


Table 3. Amino acid sequence of pepsin-digested cytochrome c 'core'

\begin{tabular}{|c|c|}
\hline Dipeptides & 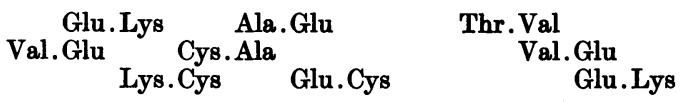 \\
\hline Tripeptides & 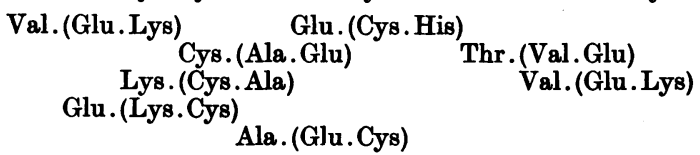 \\
\hline Tetrapeptides & $\begin{array}{l}\text { Lys.(Cys.Ala.Glu) } \\
\text { Val.(Glu.Lys.Cys) }\end{array}$ \\
\hline croapcpucos & Val.(Glu.Lys.Cys.Ara) \\
\hline Tinal sequence & Val.Glu.Lys.Cys.Ala.Glu.Cys.His.Thr.Val.Glu.Lys \\
\hline
\end{tabular}

this sequence, was also isolated by Tuppy \& Bodo (1954b), who showed that it was probably formed by a transfer reaction during acid hydrolysis. No peptide containing both histidine and threonine could be isolated, but the sequence given above is the only one fitting the results presented, in view of the valyl $N$-terminal residue (Table 1 ).

These results are in accord with those obtained by Tuppy \& Paleus (1955) with pepsin-digested ox and chicken-heart cytochrome $c$ 'core', except for the extra $C$-terminal lysine, which did not appear in the pepsin-digested material of these authors. Moreover, the preparations used in this study regularly contained somewhat more than 1.0 mole of alanine and a fraction of a mole of leucineisoleucine, which on paper chromatography with the tert.-amyl alcohol-phthalate buffer solvent of Blackburn \& Lowther (1951) was shown to consist mainly of leucine with a trace of isoleucine. No position could be assigned with certainty to the second alanine and to the leucine residues; in one preparation only, two peptides could be isolated that indicated positions at the $N$-terminal end of the peptide. No attempt was made to determine which of the glutamic acid residues were in the form of glutamine.

Properties of the haemochromogens of various cytochrome c fractions and of the pepsin-digested cytochrome c 'core'

Fig. 2 shows the effect of $\mathrm{pH}$ on the extinction coefficient at $550 \mathrm{~m} \mu$ of the reduced forms of native cytochrome $c$ (fraction I), of the chromatographic fractions separated from the partially 'unfolded' or 'denatured' mixture termed fraction II (Margoliash, 1954b) and of the pepsin-digested cytochrome $c$ 'core'. Fig. 3 compares the enzymic activity of these various forms of the cytochrome $c$ haemochromogen in the cytochrome oxidase and succinic oxidase systems, as well as their rate of ascorbic acid oxidation; in Fig. 4 their percentage combination with $\mathrm{CO}$ at various $\mathrm{pH}$ values is shown.

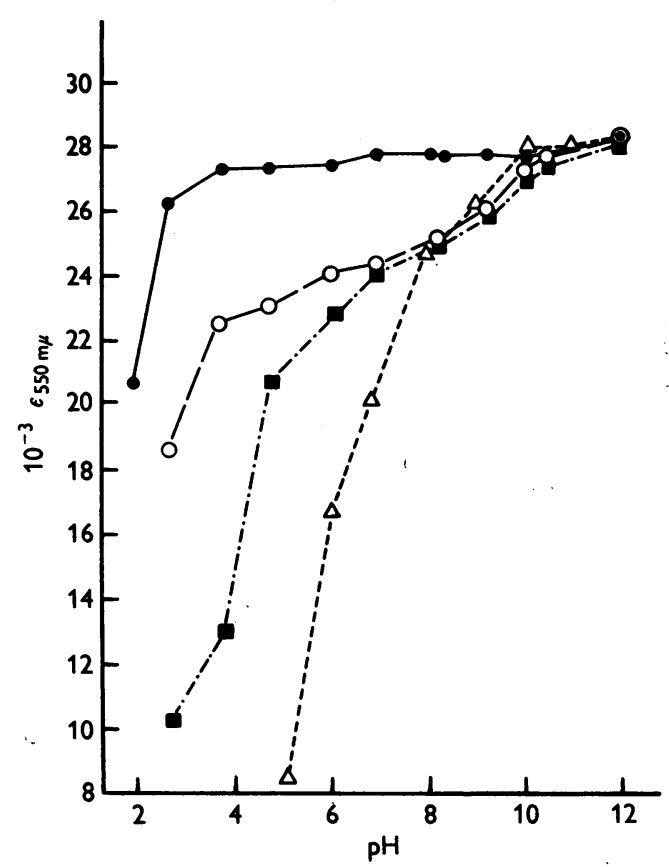

Fig. 2. Effect of $\mathrm{pH}$ on the extinction coefficient at $550 \mathrm{~m} \mu$ of the reduced form of various cytochrome $c$ fractions. Fraction I; O, fraction II $a ; \square$, fraction II $b ; \Delta$, pepsin-digested cytochrome $c$ 'core'.

These results show that although the reduced spectrum of native cytochrome $c$, as estimated by the absorption at $550 \mathrm{~m} \mu$ ( $\alpha$-band), is relatively independent of pH down to $\mathrm{pH} \mathrm{3,} \mathrm{as} \mathrm{is} \mathrm{well} \mathrm{known,}$ the more the protein is 'unfolded' (as in fractions II $a$ and IIb) the higher the $\mathrm{pH}$ at which the reduced spectrum becomes relatively independent of the $\mathrm{pH}$, the lower the enzymic activity, the higher the rate of ascorbic acid oxidation and the lower the lowest $\mathrm{pH}$ at which there is complete combination with $\mathrm{CO}$. The most degraded form of the cytochrome $c$ hremochromogen used in this study was the pepsin-digested cytochrome $c$ 'core', 
with minimal enzymic activity, a very high rate of ascorbic acid oxidation, a reduced spectrum (the height of which varied with the $\mathrm{pH}$ throughout the range tested, the $\alpha$-band reaching the full extinction of that of native cytochrome $c$ only at $\mathrm{pH}$ 11) and complete combination with $\mathrm{CO}$ at all $\mathrm{pH}$ values tested. The 'core' in fact acted as a common haemochromogen formed from haem and ordinary organic bases.

\section{Model of pepsin-digested cytochrome c 'core' and degrees of polymerization in solution}

There are three groups in the peptide of the pepsin-digested cytochrome $c$ 'core' that can form haemochromogen bonds with the haem iron: the imidazole group of the histidine residue, the $\epsilon$ amino group of the lysine and the $N$-terminal $\alpha$ amino group of the valine. In order to test whether the formation of an intramolecular haemochromo-

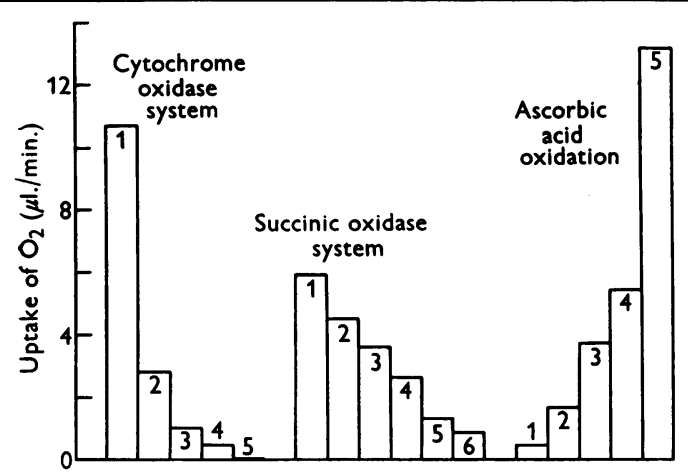

Fig. 3. Catalytic effects in the cytochrome oxidase and succinic oxidase systems and rates of ascorbic acid oxidation of various cytochrome $c$ fractions, and of the pepsin-digested cytochrome $c$ 'core'. Fraction I (1), fraction II $a(2)$, fraction II $b(3)$, fraction II $c(4)$, pepsindigested cytochrome $c$ 'core' (5) and, for succinic oxidase system, a control flask containing no added cytochrome $c$ (6). For the cytochrome oxidase system and for the rate of ascorbic acid-oxidation tests each flask contained: 0.066 м-phosphate buffer, pH 7.3, mm-ethylenediaminetetra-acetic acid, $10 \mathrm{mg}$. of ascorbic acid and $10 \mu \mathrm{g}$. of cytochrome $c$ iron; for the cytochrome oxidase system $0.265 \mathrm{mg}$. of heart-muscle preparation (fat-free dry wt.) was also added. The values for the $\mathrm{O}_{2}$ uptake were obtained by deduction of the $\mathrm{O}_{2}$ uptake of the controls containing all the ingredients except the oxidase preparation (for cytochrome oxidase system) or cytochromec (for ascorbic acid oxidation) from that of the complete system. For the succinic oxidase system each flask contained: $0.15 \mathrm{M}$-phosphate buffer, $\mathrm{pH} \mathrm{7.3,0.024 \textrm {M } -}$ succinate, $0.530 \mathrm{mg}$. of cytochrome c-deficient heartmuscle preparation (fat-free dry wt.) and $5 \mu \mathrm{g}$. of cytochrome $c$ iron in all flasks except in control (6). The cytochrome $c$-deficient heart-muscle preparation was made according to Tsou (1952). For all systems the total volume of fluid was $3.3 \mathrm{ml}$./flask, temperature $37^{\circ}$; the $\mathrm{O}_{2}$ uptake was found to be linear for at least $30 \mathrm{~min}$. gen with these groups was possible, an atomic model of the haem and its attached peptide was built. The haem and the imidazole group consisted of carved wooden models kindly provided by Professor P. George, and all the other atoms were Catalin plastic models (Catalin Products Ltd.). The scale was $1 \mathrm{~cm}$. to $1 \AA$. The two thio ether bonds were fixed in either of the two possible alternative positions (the cysteine next to the lysine residue to the vinyl side-chain on ring II of the haem, and the other cysteine to the vinyl group on ring $I$, or the opposite arrangement), the amino acids were assumed to have the L-configuration, and the peptide bonds were kept coplanar. It was found that in each case there was a position of the chain in which the imidazole group and the $\epsilon$-amino group of the lysine next to the cysteine could coordinate with the central haem-iron atom from opposite sides of the haem plane. In this position the peptide chain was nearly fully extended and there did not appear to be any considerable degree of strain. An intramolecular haemochromogen was thus sterically possible. In confirmation of part of the results of Ehrenberg \& Theorell (1955), who investigated helical formations of the peptide chain, it was found that with $\alpha$-helices (Pauling, 1953) only one of the above two groups could in any one position be made to co-ordinate with the haem iron.

In view of the ease of polymerization of haems in solution and the conclusion of Ehrenberg \& Theorell (1955) that the pepsin-digested ox-heart cytochrome $c$ 'core' at $\mathrm{pH} 8.7$ consisted of a

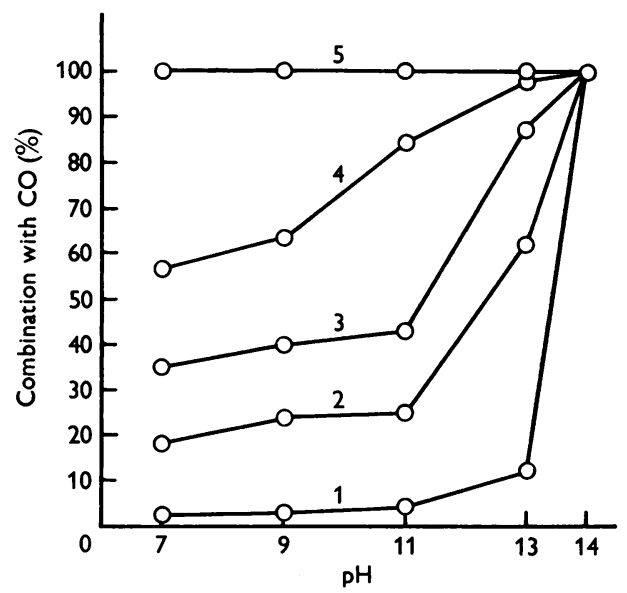

Fig. 4. Effect of $\mathrm{pH}$ on the combination of various cytochrome $c$ fractions and of pepsin-digested cytochrome $c$ 'core' with CO. Fraction I (1), fraction II $a$ (2), fraction II $b(3)$, fraction II $c(4)$ and pepsin-digested cytochrome $c$ 'core' (5). Percentage combination with CO was estimated according to Tsou (1951 $a)$ in a spectrophotometer cell fused to a Thunberg tube and under an atmosphere of pure CO. Buffers used are given under Methods. 
Table 4. Sedimentation coefficients of the pepsin-digested cytochrome c 'core'

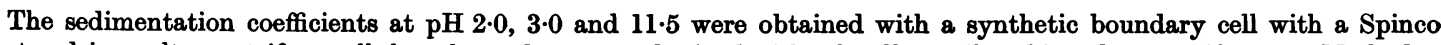
motor-driven ultracentrifuge; all the other values were obtained with a Svedberg oil-turbine ultracentrifuge (see Methods).

\begin{tabular}{|c|c|c|c|c|}
\hline $\mathrm{pH}$ & Buffer & $\begin{array}{l}\text { Concn. } \\
\text { (mg./ml.) }\end{array}$ & Form & $10^{13} S_{20}$ \\
\hline $2 \cdot 1$ & $0.1 \mathrm{M}$-Sodium acetate titrated with $0.1 \mathrm{~N}-\mathrm{HCl}$ & $2 \cdot 5$ & Oxidized & $1 \cdot 01$ \\
\hline $3 \cdot 0$ & $0.1 \mathrm{~m}$-Sodium acetate titrated with $0.1 \mathrm{~N}-\mathrm{HCl}$ & $2 \cdot 5$ & Oxidized & 1.00 \\
\hline $3 \cdot 12$ & $0.1 \mathrm{M}$-Citric acid-0.05 $\mathrm{N}-\mathrm{NaOH}$ & $5 \cdot 6$ & Oxidized & $1 \cdot 02$ \\
\hline $6 \cdot 20$ & $0.075 \mathrm{M}-\mathrm{KH}_{2} \mathrm{PO}_{4}-0.025 \mathrm{M}-\mathrm{K}_{2} \mathrm{HPO}_{4}$ & $5 \cdot 1$ & Reduced & 1.57 \\
\hline $6 \cdot 50$ & $0.075 \mathrm{M}-\mathrm{KH}_{2} \mathrm{PO}_{4}-0.025 \mathrm{~m}-\mathrm{K}_{2} \mathrm{HPO}_{4}$ & $5 \cdot 1$ & Oxidized & $1 \cdot 46$ \\
\hline $7 \cdot 52$ & $0.095 \mathrm{M}-\mathrm{K}_{2} \mathrm{HPO}_{4}-0.005 \mathrm{M}-\mathrm{KH}_{2} \mathrm{PO}_{4}$ & $\mathbf{5 \cdot 2}$ & Reduced & 1.45 \\
\hline $7 \cdot 92$ & $0.095 \mathrm{M}-\mathrm{K}_{2} \mathrm{HPO}_{4}-0.005 \mathrm{M}-\mathrm{KH}_{2} \mathrm{PO}_{4}$ & $\mathbf{5 \cdot 2}$ & Oxidized & $\mathbf{1} \cdot \mathbf{3 6}$ \\
\hline $10 \cdot 00$ & $0.1 \mathrm{M}-\mathrm{K}_{2} \mathrm{HPO}_{4}-0.05 \mathrm{~N}-\mathrm{NaOH}$ & $5 \cdot 6$ & Reduced & $1 \cdot 20$ \\
\hline $10 \cdot 46$ & $0.1 \mathrm{M}-\mathrm{Na}_{8} \mathrm{CO}_{3}-0.023 \mathrm{~N}-\mathrm{HCl}$ & $5 \cdot 7$ & Oxidized & $1 \cdot 22$ \\
\hline $10 \cdot 46$ & $0.1 \mathrm{M}-\mathrm{Na}_{2} \mathrm{CO}_{3}-0.023 \mathrm{~N}-\mathrm{HCl}$ & $5 \cdot 7$ & Reduced & $1 \cdot 16$ \\
\hline $11 \cdot 5$ & $0 \cdot 1 \mathrm{M}-\mathrm{Na}_{2} \mathrm{CO}_{3}$ titrated with $0.1 \mathrm{~N}-\mathrm{NaOH}$ & $2 \cdot 5$ & Oxidized & $1 \cdot 09$ \\
\hline $12 \cdot 4$ & $0.14 \mathrm{M}-\mathrm{Na}_{2} \mathrm{CO}_{3}-0.02 \mathrm{~N}-\mathrm{NaOH}$ & $5 \cdot 1$ & Reduced & 0.94 \\
\hline
\end{tabular}

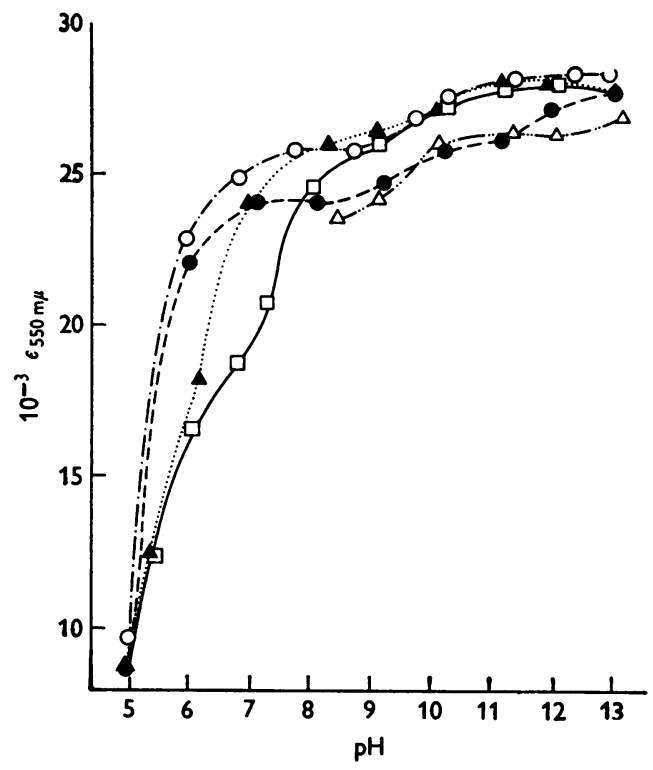

Fig. 5. Effect of $\mathrm{pH}$ on the extinction coefficient at $550 \mathrm{~m} \mu$ of the reduced form of the pepsin-digested cytochrome $c$ 'core' alone $(\square)$ and in the presence of a 2000 molar excess of imidazole (O), $\alpha$-benzoylhistidine $(\triangle)$, butylamine $(\Delta)$ and histidine $(O)$. Techniques used for determining the extinction and the final $\mathrm{pH}$ of the solutions as well as the buffers used are given under Methods. Added substances were dissolved in buffer solutions. Final concentrations: pepsin-digested cytochrome $c$ 'core': $2.60 \times 10^{-5}$ g.atoms of $\mathrm{Fe} / \mathrm{l}$.; buffers: $0 \cdot 1 \mathrm{M}$.

monodisperse pentamer or hexamer, as calculated from sedimentation data, the possibility had to be considered that the reduced haemochromogen spectrum observed with the 'core' used in this study was due to an intermolecular co-ordination of basic groups to the iron. The results of the study of the sedimentation properties of the pepsin- digested cytochrome c 'core' are presented in Table 4. At pH 4-5 the material was too insoluble for determinations to be made. At $\mathrm{pH} \mathrm{6.2} \mathrm{the}$ sedimentation coefficient $\left(S_{20}\right)$ was $1.57 \times 10^{-13}$ and fell with increasing alkalinity to $0.94 \times 10^{-13}$ at pH 12.4. At pH 3.12 a low $S_{20}$ of $1.02 \times 10^{-13}$ was again obtained, and in those experiments carried out with a synthetic boundary cell no significant

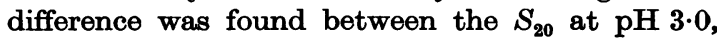
2.0 and 11.5. No significant difference was found between the oxidized and reduced 'cores'.

Variation with $\mathrm{pH}$ of the reduced spectrum of the various forms of the cytochrome $\mathrm{c}$ haemochromogen

Fig. 5 shows the $\mathrm{pH}-\epsilon_{550 \mathrm{~m} \mu}$ curve for the reduced form of the pepsin-digested cytochrome $c$ 'core' alone and with the addition of a 2000 molar excess of butylamine $\left(\mathrm{pK} K^{\prime}\right.$ for $\left.\mathrm{NH}_{3}{ }^{+} \rightleftharpoons \mathrm{NH}_{2}: 10 \cdot 6\right)$, imidazole $\left(\mathrm{p} K^{\prime}\right.$ for $\left.\mathrm{NH}_{2}{ }^{+} \rightleftharpoons \mathrm{NH}: 6.5\right)$, histidine ( $K^{\prime}$ for imidazole $\mathrm{NH}_{2}{ }^{+} \rightleftharpoons \mathrm{NH}: 6 \cdot 1$; for $\alpha-\mathrm{NH}_{3}{ }^{+} \rightleftharpoons \mathrm{NH}_{2}: 8 \cdot 6$ ) and $\alpha$-benzoylhistidine, in which only the imidazole ring is free to bind the haem iron at neutral or alkaline $\mathrm{pH}$.

The curve for the 'core' without any addition reached the full extinction of cytochrome $c$ only at pH 11, and showed three inflexions which may be interpreted as corresponding to the $\mathrm{p} K^{\prime}$ values of the combination with haem iron of the imidazole group, a peptide $\alpha$-amino group and the $\epsilon$-amino group of lysine. These $\mathrm{p} K^{\prime}$ values were roughly estimated as 5.4, 7.6 and 9.5 respectively.

In the presence of a large excess of added bases that can bind the haem iron, these bases compete with the iron co-ordinating groups in the peptide. It will be noted in Fig. 5 that the $\alpha$-band of the 'core' alone, with the addition of butylamine containing an amino group similar to the $\epsilon$-amino group of lysine, or with the addition of histidine containing a free $\alpha$-amino group, reached the extinction of native cytochrome $c$ at $\mathrm{pH} 11$. On the other hand, when the added base had only an 
imidazole group free, as with imidazole and $\alpha$ benzoylhistidine, the maximal extinction reached at $\mathrm{pH} 11$ was $5-8 \%$ below that of native cytochrome $c$. This difference was constant and particular care was taken to eliminate volumetric errors by using the same solution of 'core' for all the curves. Maximal values similar to those given by the 'core' in the presence of histidine and butylamine were obtained with the addition of lysine and glycine. Above $\mathrm{pH} 11$ the curves with added imidazole and $\alpha$-benzoylhistidine tended to approach that of the 'core' without any addition. This was probably because at these extreme alkaline $\mathrm{pH}$ values the imidazole group ionized as an acid and could therefore not form haemochromogen links with the iron atom.

Table 5 lists the following ratios of the extinction values of the various forms of the cytochrome $c$ haemochromogen in the reduced state: $\epsilon_{550 \mathrm{~m} \mu} / \epsilon_{520 \mathrm{~m} \mu}$ ( $\alpha$-band $/ \beta$-band), $\epsilon_{550 \mathrm{~m} \mu} / \epsilon_{535 \mathrm{~m} \mu}(\alpha$-band $/$ minimum $)$ $\epsilon_{520 \mathrm{~m} \mu} / \epsilon_{535 \mathrm{~m} \mu}$ ( $\beta$-band $/$ minimum) and $\epsilon_{590 \mathrm{~m} \mu}$ oxidized/ $\epsilon_{590 \mathrm{~m} \mu}$ reduced. This last ratio was found by Henderson \& Rawlinson (1956) to be the most sensitive spectrophotometric indication of the purity of different cytochrome $c$ preparations.

These results, which give a more accurate estimation of the spectral changes than the overall picture given in Fig. 5, show that the extinction ratios of fraction I (native, fully enzymically active cytochrome c) do not change appreciably between $\mathrm{pH} 7.0$ and 11.0 , whereas the spectrum of the 'core' approaches that of native cytochrome $c$ only at the more alkaline $\mathrm{pH}$. The main differences between the spectrum of the 'core' and fraction I were: (a) the minimum at $535 \mathrm{~m} \mu$ (reduced) was always considerably higher than that of fraction $I$ even at the alkaline $\mathrm{pH}$, at which the extinctions of the $\alpha$-band maximum was similar to those of fraction I, and $(b)$ the ratio $\epsilon_{590 \mathrm{~m} \mu}$ oxidized $/ \epsilon_{590 \mathrm{~m} \mu}$ reduced was very considerably higher for fraction $I$ than for the 'core' at all $\mathrm{pH}$ values tested.

The behaviour of fraction II $c$ was intermediate between that of fraction I and the 'core'.

The addition of a 2000 molar excess of butylamine to the 'core' did not change appreciably its spectrum at alkaline $\mathrm{pH}$ values, having in particular no effect on the extinction at the minimum $(535 \mathrm{~m} \mu)$. On the other hand, the addition of a 2000 molar excess of imidazole caused, at alkaline $\mathrm{pH}$ values, a decrease of the extinction of the $\alpha$ band and moved the ratio $\epsilon_{590 \mathrm{~m} \mu}$ oxidized $/ \epsilon_{590 \mathrm{~m} \mu}$ reduced even further away from that obtained with fraction I. Imidazole did not affect the extinction of the 'core' at the minimum $(535 \mathrm{~m} \mu)$.

In conclusion it may be stated that, under conditions favouring the formation of a di-imidazole haemochromogen, the spectrum of the 'core' was farther away from that of native cytochrome $c$ than was the spectrum of the 'core' alone at the alkaline $\mathrm{pH}$ at which it approached that of fraction $I$.

\section{DISCUSSION \\ Peptide structure}

The amino acid sequence worked out above for the pepsin-digested horse-heart cytochrome c 'core' was the same as that obtained by Tuppy \& Paleus (1955) for ox and chicken cytochrome $c$, but included in addition a $C$-terminal lysine found by Tuppy \& Bodo $(1954 b, c)$ in the preparations obtained by tryptic digestion of horse-, ox- and pigheart cytochrome $c$. This difference was probably due to the use, in the present study, of nonpurified preparations of the 'core', which included

Table 5. Effect of $\mathrm{pH}$ on extinction-coefficient ratios of various forms of the cytochrome $\mathrm{c}$ haemochromogen

The concentrations of the haemochromogens were adjusted so that the extinction coefficients in the actual readings were between $\mathbf{0 . 2}$ and $\mathbf{0 . 9}$. A single solution was used for each substance, for the readings at 520,535 and $550 \mathrm{~m} \mu$, and a more concentrated solution for the readings at $590 \mathrm{~m} \mu$. $\mathrm{pH}$ was determined with a glass electrode. The imidazole and butylamine were at a molar concentration 2000 times the molar concentration of the 'core'.

\begin{tabular}{|c|c|c|c|c|c|}
\hline Haemochromogen & pH & $\begin{array}{c}\epsilon_{550 \mathrm{~m} \mu} / \epsilon_{520 \mathrm{~m}} \mu \\
(\text { reduced })\end{array}$ & $\begin{array}{c}\epsilon_{550 \mathrm{~m} \mu} / \epsilon_{535 \mathrm{~m} \mu} \mu \\
\text { (reduced) }\end{array}$ & $\begin{array}{l}\epsilon_{520 \mathrm{~m} \mu} / \epsilon_{535 \mathrm{~m}} \mu \\
\text { (reduced) }\end{array}$ & $\begin{array}{c}\epsilon_{590 \mathrm{~m} \mu} \\
(\text { reduced) }\end{array}$ \\
\hline Fraction I & $\begin{array}{r}7 \cdot 0 \\
11 \cdot 0\end{array}$ & $\begin{array}{l}1 \cdot 74 \\
1 \cdot 76\end{array}$ & $\begin{array}{l}3 \cdot 83 \\
3 \cdot 88\end{array}$ & $\begin{array}{l}2 \cdot 20 \\
2 \cdot 22\end{array}$ & $\stackrel{5 \cdot 78}{-}$ \\
\hline Fraction II $c$ & $\begin{array}{r}7 \cdot 0 \\
11 \cdot 0\end{array}$ & $\begin{array}{l}1 \cdot 72 \\
1 \cdot 77\end{array}$ & $\begin{array}{l}3 \cdot 48 \\
3 \cdot 62\end{array}$ & $\begin{array}{l}2 \cdot 02 \\
2 \cdot 04\end{array}$ & $\begin{array}{l}4 \cdot 09 \\
5 \cdot 08\end{array}$ \\
\hline 'Core' & $\begin{array}{r}7 \cdot 0 \\
9 \cdot 0 \\
11.5\end{array}$ & $\begin{array}{l}1.69 \\
1 \cdot 72 \\
1 \cdot 76\end{array}$ & $\begin{array}{l}2 \cdot 82 \\
3 \cdot 21 \\
3 \cdot 35\end{array}$ & $\begin{array}{l}1.67 \\
1.86 \\
1.90\end{array}$ & $\frac{1 \cdot 92}{2 \cdot 54}$ \\
\hline 'Core' + imidazole & $\begin{array}{r}7 \cdot 3 \\
9 \cdot 0 \\
11 \cdot 5\end{array}$ & $\begin{array}{l}1 \cdot 60 \\
1 \cdot 61 \\
1 \cdot 69\end{array}$ & $\begin{array}{l}3 \cdot 03 \\
3 \cdot 05 \\
3 \cdot 20\end{array}$ & $\begin{array}{l}1 \cdot 89 \\
1 \cdot 89 \\
1 \cdot 89\end{array}$ & $\frac{-}{2 \cdot 40}$ \\
\hline 'Core' + butylamine & $\begin{array}{r}7 \cdot 6 \\
9 \cdot 6 \\
11 \cdot 0\end{array}$ & $\begin{array}{l}1 \cdot 73 \\
1 \cdot 77 \\
1 \cdot 78\end{array}$ & $\begin{array}{l}\mathbf{3} \cdot 11 \\
\mathbf{3} \cdot 32 \\
\mathbf{3} \cdot 36\end{array}$ & $\begin{array}{l}1.80 \\
1.88 \\
1.89\end{array}$ & - \\
\hline
\end{tabular}


not only the final product of peptic hydrolysis but also a certain proportion of peptides containing the extra $C$-terminal lysine. Indeed the amino acid analysis of the preparations used gave 1.6 moles of lysine (Table 1), as compared to the $1.0 \mathrm{~mole}$ which would have been expected had the $C$-terminal lysine been entirely absent. This analysis also showed an excess of $0 \cdot 2-0 \cdot 3$ mole of alanine above that expected and about 0.2 mole of leucine. The positions of these two extra residues could not be determined.

On oxidation of the 'core' with performic acid it was found that a mixture of peptides was obtained (Fig. 1; Table 1). It is unlikely that this procedure opened the peptide bonds, in view of the results of Sanger $(1949 a)$ with insulin. Neglecting the minor products, the amino acids present in the three main products indicated that pepsin, in addition to its effect at its major sites of action, had split to a minor degree the bond between the alanine and the glutamic acid situated between the two cysteine residues. Thus the peptide bonds hydrolysed by pepsin were: $(a)$ at the amino end of the $N$-terminal valine; $(b)$ the Ala Glu bond between the cysteines; (c) the Glu Lys bond near the $C$-terminal end of the peptide; $(d)$ at the carboxyl end of the $C$. terminal lysine. In addition to these, the amino acid analyses of the preparations used indicated at least two other unidentified sites of action involving leucine and alanine. These results again emphasize the wide range of pepsin specificities and their variation from classical expectations (Fruton \& Bergmann, 1939), as was found by Sanger \& Tuppy $(1951 b)$ and Sanger \& Thompson (1953b) with insulin.

\section{Effect of 'denaturation' of cytochrome c on the properties of the haemochromogen}

Tsou (1951 $a$ ), who first prepared proteolytic digestion products from cytochrome $c$, which included the haem, demonstrated their lack of enzymic activity, their high rate of ascorbic acid oxidation (indicating rapid auto-oxidizability) and their immediate combination with $\mathrm{CO}$ at neutral $\mathrm{pH}$ values. These results were fully confirmed in the present study with the pepsin-digestion product, and it was shown in addition that the reduced spectrum was $\mathrm{pH}$-dependent, reaching the extinction values of native cytochrome $c$ only at very alkaline $\mathrm{pH}$. The 'core' acted as a common haemochromogen prepared from haem and organic bases.

Native cytochrome $c$ (fraction I) was at the other end of the scale, with high enzymic activity, low rate of ascorbic acid oxidation, combination with $\mathrm{CO}$ only at extreme alkaline $\mathrm{pH}$ values and a wide $\mathrm{pH}$ range of stability of the reduced spectrum. In between these two extremes there was a grada- tion of partially 'unfolded' or 'denatured' forms of the protein (fractions II $a$, II $b$ and II $c$ ) in which the enzymic activity was in some relation to the range of $\mathrm{pH}$ stability of the reduced spectrum, the percentage combination with $\mathrm{CO}$ at various $\mathrm{pH}$ values and the rate of ascorbic acid oxidation. The order in which the various fractions II were eluted from the cation-exchange column was presumably the order of increasing availability of $\epsilon$-amino groups on the surface of the protein, indicating increasing degrees of 'unfolding'. Thus it was probably the whole cytochrome $c$ protein in its native spatial configuration which endowed the molecule with its particular properties, distinguishing it from ordinary haemochromogens.

\section{Haemochromogen-forming groups in cytochrome c}

Ehrenberg \& Theorell (1955) conclude that: (a) the haemochromogen of the pepsin-digested cytochrome $c$ 'core' is a result of the polymerization of the molecule at neutral and slightly alkaline $\mathrm{pH}$ values (i.e. an intermolecular haemochromogen), and $(b)$ if the peptide chain of the 'core' is made into an $\alpha$-helix, either the histidine imidazole group, or the $\epsilon$-amino group of the lysine residue next to the cysteine, can be made to co-ordinate with the haem iron, but not both groups simultaneously. On the basis of their conclusions these authors support the view that the haemochromogenforming groups of cytochrome $c$ are two imidazole groups, one from the histidine residue present in the 'core' and the other from another histidine elsewhere in the molecule.

However, the finding of a lysine, or an arginine, and a histidine adjacent to the two cysteines binding the cytochrome $c$ to the haem, in all the cytochromes so far examined (see Tuppy \& Paleus, 1955, for ox, chicken and salmon cytochrome $c$, and Tuppy \& Bodo, 1954a-c, for horse- and pig-heart cytochrome $c$ ), can lead to the alternative hypothesis that the imidazole and $\epsilon$-amino groups on these amino acids are in fact the haemochromogenforming groups in native cytochrome $c$. Moreover, an atomic model has shown that such an arrangement is sterically possible if the intervening chain of four amino acids was fully extended. This second hypothesis, however, raised a number of problems, discussed below.

Interpretation of spectrophotometrically operable $\mathrm{p} K$ values. Paleus et al. (1955), using the absorption at wavelengths of 395 and $410 \mathrm{~m} \mu$, demonstrated the presence of two dissociation steps with $\mathrm{p} K^{\prime}$ values of 3.4 and 5.8 respectively for the oxidized form of pepsin-digested ox-heart cytochrome $c$ 'core'. These were interpreted by Ehrenberg \& Theorell (1955) as representing the combination of an imidazole at $\mathrm{p} K^{\prime} 3 \cdot 4$, and an $\alpha$-amino group at $\mathrm{p} K^{\prime} \mathbf{5 \cdot 8}$, to the haem iron. The results obtained 
above with the peak of the $\alpha$-band $(550 \mathrm{~m} \mu)$ of the reduced form of the 'core' from horse-heart cytochrome $c$, indicated the presence of three $\mathrm{pK}^{\prime}$ values, which were roughly estimated as $5 \cdot 4,7 \cdot 6$ and 9.5. These values were interpreted as being due to the combination with haem of an imidazole, an $\alpha$-amino and an $\epsilon$-amino group respectively. The $\mathrm{p} K^{\prime}$ of about 5.4 could well represent the same dissociation step which was assigned a $\mathrm{p} K^{\prime}$ of $5 \cdot 8$ by Paleus et al. (1955). The $\mathrm{p} K^{\prime}$ values for the combination of a base with the haem iron are commonly considered to be as much as several $\mathrm{pH}$ units below the $\mathrm{p} K^{\prime}$ of the base, particularly in haemoproteins, since the haem iron by combining only with the un-ionized form of the base shifts the equilibrium in favour of this form. In the present case, if the interpretation of the $\mathrm{p} K^{\prime}$ values given above is accepted, the 'acidifying' effect was relatively small: from $6 \cdot 1$ to about $5 \cdot 4$ for the imidazole group and from 10.5 to 9.5 for the $\epsilon$-amino group. The presumed $\alpha$-amino group $\mathrm{p} K^{\prime}$ was estimated as $7 \cdot 6 ; N$-terminal amino groups in simple peptides give $\mathrm{p} K^{\prime}$ values of about $7 \cdot 5-8 \cdot 5$ (Cohn \& Edsall, 1943) and a valyl $N$-terminal amino group would be expected to have a $\mathrm{p} K^{\prime}$ of about 8.0. However, in the present case the reaction of haemochromogen formation competed not only with the ionization of the basic groups but possibly also with the reaction of polymerization of the whole molecule. This secondary reaction might be the reason for the relatively small shifts observed in the $\mathrm{p} K^{\prime}$ values. Moreover, the peptide of the 'core' is not fixed in its position, and haemochromogen formation can be considered to be a less favoured reaction than in the native cytochrome $c$ molecule, in which the haemochromogen-forming groups are probably held close to the haem iron. On the other hand, the authors are unaware of any clear demonstration that the co-ordination of bases with haem iron does in fact occur at $\mathrm{pH}$ values below the $\mathrm{p} K^{\prime}$ of the base by as much as several $\mathrm{pH}$ units. In this respect it might be mentioned that Ehrenberg \& Theorell (1955) did not find any combination of glycylglycine $\left(\mathrm{p} K^{\prime}\right.$ of free amino group for $\mathrm{NH}_{3}{ }^{+} \rightleftharpoons \mathrm{NH}_{2}: 8 \cdot 1-8 \cdot 2$, Cohn \& Edsall, 1943) with ferri- or ferro-protoporphyrin at pH 7.0. This combination would have been expected to occur, had the 'acidifying' effect been of even half the magnitude assumed by these authors for the imidazole and $\alpha$-amino groups in the 'core'.

Polymerization of the pepsin-digested cytochrome $\mathrm{c}$ 'core'. Ehrenberg \& Theorell (1955) have interpreted the results of ultracentrifuging as showing that the pepsin-digested cytochrome $c$ 'core' in the oxidized form at $\mathrm{pH} \mathrm{8.7}$ consisted of a monodisperse pentamer or hexamer. The typical reduced spectrum could thus be well due to the formation of an intermolecular haemochromogen. However, if the formation of the haemochromogen was solely due to an intermolecular co-ordination, one would expect the degree of polymerization to increase with the increase in the height of the haemochromogen spectrum. Actually it was found that the more alkaline the $\mathrm{pH}$ the lower was the sedimentation coefficient, and simultaneously the height of the reduced $\alpha$-band at $550 \mathrm{~m} \mu$ increased until at $\mathrm{pH} 11$ it was indistinguishable from that of native cytochrome $c$. At alkaline $\mathrm{pH}$ values the sedimen-

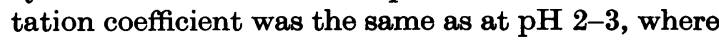
the 'core' can only be monomeric. Thus, if variations of the sedimentation coefficient are considered to be due to changes in the degree of polymerization, the 'core' was monomeric at alkaline $\mathrm{pH}$ values at which its spectrum showed the nearest approach to that of native cytochromec, and the formation of an intramolecular haemochromogen is indicated.

The relatively high sedimentation coefficients obtained at $\mathrm{pH}$ values between 6.2 and 7.5 were similar to those obtained by Ehrenberg \& Theorell (1955) at $\mathrm{pH} \mathrm{8.7}$ and may indicate that the weak haemochromogen spectrum observed in this $\mathrm{pH}$ range was associated with polymerization of the molecule, and thus with an intermolecular haemochromogen. This observation cannot, however, be used as an argument in favour of a helical structure of the peptide between the two haemochromogenforming groups in the 'core', a structure which excludes an intramolecular haemochromogen, since such an intramolecular haemochromogen was probably present at the appropriate alkaline $\mathrm{pH}$ value. The arrangement of the haemochromogen does not have any bearing on the peptide chain elsewhere in the molecule, which may well have a helical arrangement as indicated by the X-ray analysis of Arndt \& Riley (1955).

Variation of the reduced spectrum of the 'core' with $\mathrm{pH}$ and in the presence of added bases. Under conditions favouring the formation of a di-imidazole haemochromogen (i.e. with the addition of a large excess of imidazole-containing bases), the spectrum of the 'core' was further away from that of native cytochrome $c$ than was the spectrum of the 'core' alone or with the addition of bases containing $\alpha$ - or $\epsilon$-amino groups. Even though the 2000 molar excess of added imidazole may not have resulted in the complete formation of a di-imidazole haemochromogen, the extinction value for the reduced $\alpha$-band maximum was $5-8 \%$ lower than the maximal value obtained with the 'core' or with native cytochrome $c$ at $\mathrm{pH} 11$, indicating that the original cytochrome $c$ haemochromogen, at least at $\mathrm{pH}$ 11, was not formed by two imidazole groups.

Moreover, if the interpretation of the first inflexion of the $\mathrm{pH}$-spectrum curves as being due to 
the imidazole $\mathrm{p} K^{\prime}$ is correct, the haemochromogenforming groups in cytochrome $c$ consist of an imidazole group on one side of the haem and an $\alpha$ or $\epsilon$-amino group on the other, as would be expected if the corresponding groups in the 'core' were the groups actually involved in the native molecule. The experiments reported above did not distinguish between the spectral contribution of an $\alpha$-amino as compared with an e-amino group.

The fact that the reduced spectrum of the 'core' approached that of cytochrome $c$ only at alkaline $\mathrm{pH}$ values does not necessarily mean that the haemochromogen-forming groups are different. Indeed, the remarkable stability of the reduced spectrum of cytochrome $c$ over a wide range of $\mathrm{pH}$ values is probably an expression of the particular structural arrangement of the intact protein, which cannot be expected to be apparent in the fragment of the protein used in this study.

However, a far-reaching interpretation based on spectral differences of 5-8\% cannot be entirely convincing, even though these differences were well above the experimental error. The authors are nevertheless not aware of any other interpretation of their results.

Spectral changes during digestion of cytochrome c with pepsin. A final difficulty is the observation of Tsou (1951 $a)$ that at the start of the pepsin digestion of native cytochrome $c$ the absorption of the $\alpha$-band of reduced cytochrome $c$, measured at $\mathrm{pH} 7 \cdot 3$, falls rapidly to about $50 \%$ of its starting value, returning more slowly to $70-80 \%$ of the original intensity. This possibly indicates the formation of a new haemochromogen during digestion, in direct opposition to the hypothesis that the haemochromogen-forming groups in native cytochrome $c$ are present in the pepsindigested cytochrome $c$ 'core'.

However, if it is considered that the haemochromogen-forming groups in native cytochrome $c$ are held in position by the whole protein molecule, and that the haemochromogen spectrum of the 'core' at near neutral $\mathrm{pH}$ values depends on the polymerization of the 'core', it may well be that no 'core' haemochromogen can be formed in the early stages of proteolytic digestion at a time when the protein is already sufficiently broken up to prevent it from fixing the haemochromogenforming groups in their original position.

The results presented above explain why the absorption of the $\alpha$-band in Tsou's observation did not return to the original value, since digestion with pepsin had rendered the haemochromogen pH-dependent, and at $\mathrm{pH} 7 \cdot 3$, at which Tsou determined the spectrum, the absorption is in fact only about $80 \%$ of the maximum.

\section{SUMMARY}

1. The amino acid sequence of that part of the horse-heart cytochrome $c$ protein remaining attached to the haem after digestion with pepsin ('core') has been shown to be identical with that demonstrated by Tuppy \& Paleus (1955) for oxand chicken-heart cytochrome $c$.

2. It was possible to separate by cation-exchange column chromatography a series of 'denatured' cytochromes $c$ having properties ranging from those characteristic of native cytochrome $c$ to those of the pepsin-digested cytochrome $c$ 'core'; the properties studied included enzymic activity in the cytochrome oxidase and succinic oxidase systems, rate of ascorbic acid oxidation, $\mathrm{pH}$ range of stability of the reduced spectrum and percentage combination with carbon monoxide at various $\mathrm{pH}$ values.

3. The formation of an intramolecular haemochromogen in the pepsin-digested cytochrome $c$ 'core' probably occurred at alkaline $\mathrm{pH}$ values (pH 11-12). That this was sterically possible was shown by an atomic model, and required an unfolded peptide chain of four amino acids between the two presumed haemochromogenforming groups.

4. The visible spectrum of the 'core', in the reduced state, approached that of native reduced cytochrome $c$ at alkaline $\mathrm{pH}$ values, but did not coincide with it. The addition of a large excess of haemochromogen-forming bases, containing $\alpha$ - or $\epsilon$-amino groups, did not affect the extinction of the $\alpha$-band maximum of the 'core' at this alkaline $\mathrm{pH}$, whereas the addition of imidazole-containing bases decreased it by 5-8\%. This was interpreted as evidence that the haemochromogen-forming residues in cytochrome $c$ are probably not both histidines, at least at $\mathrm{pH} 11$.

5. The hypothesis that the imidazole group of the histidine next to the cysteine and the $\epsilon$-amino group of the lysine next to the other cysteine, in the pepsin-digested cytochrome c 'core', are the haemochromogen-forming groups in native cytochrome $c$ is discussed.

The authors are very grateful to Dr E. O. Field of the Department of Biochemistry (Radcliffe Infirmary), University of Oxford, for most of the ultracentrifuge studies, and to Dr A. G. Ogston for permission to use the ultracentrifuge at Oxford. They would also like to thank Dr M. Gehatia, of the Weizmann Institute, Rehovoth, for the ultracentrifuge determinations with his special synthetic boundary cell. Part of the expenses of this work were covered by grants from the Cancer Trustees, London, and the Hebrew University-Hadassah Medical School, Jerusalem. 


\section{REFERENCES}

Acher, R. \& Crocker, C. (1952). Biochim. biophys. Acta, 9, 704.

Arndt, U. W. \& Riley, D. P. (1955). Phil. Trans. 247 A, 409. Blackburn, S. \& Lowther, A. G. (1951). Biochem. J. 48, 126. Cecil, R. \& Ogston, A. G. (1948). Biochem. J. 43, 592.

Cohn, E. J. \& Edsall, J. T. (1943). Proteins, Amino-acids and Peptides, pp. 84 and 85. New York: Reinhold Publishing Corp.

Consden, R., Gordon, A. H. \& Martin, A. J. P. (1949). Biochem. J. 44, 548 .

Ehrenberg, A. \& Theorell, H. (1955). Acta chem. scand. 9, 1193.

Fowden, L. (1951). Biochem. J. 48, 327.

Fruton, J. S. \& Bergmann, M. (1939). J. biol. Chem. 127, 627.

Henderson, R. W. \& Rawlinson, W. A. (1956). Biochem. J. 62, 21.

Keilin, D. \& Hartree, E. F. (1945). Biochem. J. 39, 289.

Leaf, G. \& Gillies, N. E. (1955). Biochem. J. 61, vii.

Letonoff, T. V. \& Reinhold, J. G. (1936). J. biol. Chem. 114, 147.

Lockhart, I. M. \& Abraham, E. P. (1954). Biochem. J. 58, 633.

Macpherson, H. T. (1942). Biochem. J. 36, 59.

Margoliash, E. (1954a). Biochem. J. 56, 529.

Margoliash, E. (1954b). Biochem. J. 56, 535.
Margoliash, E. (1955). Comm. 3rd Int. Congr. Biochem., Brussels, p. 10.

Paleus, S., Ehrenberg, A. \& Tuppy, H. (1955). Acta chem. scand. 9, 365.

Paul, K. G. (1950). Acta chem. scand. 4, 239.

Paul, K. G. (1951). Acta chem. scand. 5, 389.

Pauling, L. (1953). Les Proteines: Neuvieme Conseil de Chimie Solvay, Brussels, p. 63.

Philpot, J. St L. (1938). Nature, Lond., 141, 283.

Sanger, F. (1949a). Biochem. J. 44, 126.

Sanger, F. $(1949 b)$. Biochem. J. 45, 563.

Sanger, F. \& Thompson, E. O. P. (1953a). Biochem. J. 53, 353.

Sanger, F. \& Thompson, E. O. P. (1953b). Biochem. J. 53, 366.

Sanger, F. \& Tuppy, H. (1951 a). Biochem. J. 49, 463.

Sanger, F. \& Tuppy, H. (1951b). Biochem. J. 49, 481.

Theorell, H. (1938). Biochem. Z. 298, 242.

Theorell, H. (1939). Enzymologia, 6, 88.

Tsou, C. L. (1951 a). Biochem. J. 49, 362.

Tsou, C. L. $(1951 b)$. Biochem. J. 49, 367.

Tsou, C. L. (1952). Biochem. J. 50, 493.

Tuppy, H. (1957). Cited by Bailey, K. (1957). Nature, Lond., 180, 833.

Tuppy, H. \& Bodo, G. (1954a). Mh. Chem. 85, 807.

Tuppy, H. \& Bodo, G. (1954b). Mh. Chem. 85, 1024.

Tuppy, H. \& Bodo, G. (1954c). Mh. Chem. 85, 1182.

Tuppy, H. \& Paleus, S. (1955). Acta chem. scand. 9, 353.

\title{
APPENDIX
}

\section{Spectrum of Horse-Heart Cytochrome $c$}

\author{
By E. MARGOLIASH AND NEHAMAH FROHWIRT \\ The Molteno Institute, University of Cambridge, and the Department of Experimental Pathology, \\ Hebrew University-Hadassah Medical School, Jerusalem, Israel
}

As the only published complete spectrum of cytochrome $c$ is that given by Theorell (1936) for a preparation containing $0.34 \%$ of iron, and therefore impure to the extent of about $28 \%$, it was thought worthwhile to give in detail numerical data of the spectrum of the purest preparation of the protein so far obtained, containing $0.456 \%$ of iron. A figure of this spectrum had been published in the review by Keilin \& Slater (1953).

\section{MATERIALS AND METHODS}

Preparation of cytochrome c. Chromatographic fraction I from horse-heart cytochrome $c$ was prepared by the method of Margoliash (1954), by elution from a column of Amberlite

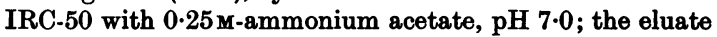
was concentrated on a second similar column, eluted with aq. $0 \cdot 2 \mathrm{M}-\mathrm{NH}_{3}$ soln. and freeze-dried over $\mathrm{H}_{2} \mathrm{SO}_{4}$. The preparation thus obtained was rechromatographed under the above conditions and only the material coming off the column at concentrations varying no more than $10 \%$ from that at the peak, during elution with $0.25 \mathrm{M}$-ammonium acetate, was used for the spectral study. The final preparation contained $\mathbf{0 . 4 5 6} \%$ of iron and was fully enzymically active in the cytochrome oxidase and succinic oxidase systems. It contained no detectable chromatographic fraction II.

Estimation of iron. This was determined by the method of Keilin \& Hartree (1945) and served as the standard for the calculation of the extinction coefficients. Repeated iron determinations agreed to within $1 \%$.

Measurement of extinction. The cytochrome $c$ was dissolved in Sørensen 0.1 M-phosphate buffer, pH 6.8. The spectrum was determined in $1 \mathrm{~cm}$. cells with a Hilger Uvispek spectrophotometer, calibrated for wavelength and extinction coefficient with standard filters provided by the National Physical Laboratory.

For the visible part of the spectrum the cytochrome $c$ solutions were reduced with buffered ( $\mathrm{pH} \mathrm{6.8)}$ cysteine solution, and for the ultraviolet spectrum the reduction was effected by platinum black $/ \mathrm{H}_{2}$ gas, the platinum black being centrifuged at the end of the reaction. The completeness of the reduction was tested at $550 \mathrm{~m} \mu$ by the addition of solid sodium dithionite. In the original solution the cytochrome $c$ was fully oxidized, the com- 